Georgia State University

ScholarWorks @ Georgia State University

$1-1-2001$

\title{
Creating a Web research guide: Collaboration between liaisons, faculty and students
}

Tammy Sugarman

Georgia State University, tsugarman@gsu.edu

Constance Demetracopoulos

Georgia State University, cdemetracopoulos1@gsu.edu

Follow this and additional works at: https://scholarworks.gsu.edu/univ_lib_facpub

Part of the Instructional Media Design Commons, and the Library and Information Science Commons

\section{Recommended Citation}

Sugarman, Tammy and Demetracopoulos, Constance, "Creating a Web research guide: Collaboration between liaisons, faculty and students" (2001). University Library Faculty Publications. 37.

https://scholarworks.gsu.edu/univ_lib_facpub/37

This Article is brought to you for free and open access by the Georgia State University Library at ScholarWorks @ Georgia State University. It has been accepted for inclusion in University Library Faculty Publications by an authorized administrator of ScholarWorks @ Georgia State University. For more information, please contact scholarworks@gsu.edu. 


\title{
Creating a Web research guide: Collaboration between liaisons, faculty and students
}

Tammy S. Sugarman

Constance Demetracopoulos

\section{Author Information}

Tammy S. Sugarman is an Instructor, History and Art and Design Liaison Librarian, and Constance

Demetracopoulos is an Assistant Professor, Philosophy and Religious Studies Liaison/Catalog Librarian, both at the William Russell Pullen Library, Georgia State University, Atlanta, Georgia, USA.

\section{Keywords}

Partnerships, Teachers, Librarians, Students, World Wide Web, History, Research

\begin{abstract}
This article discusses the efforts of two liaison librarians at William Russell Pullen Library, Georgia State University, to build a long-term, sustainable partnership among teaching faculty, graduate students, and librarians in the development and maintenance of a Web-based research guide for world history. The projects' goals are: to provide access to the resources available at Pullen Library; to serve as a gateway to resources available on the Internet; and to showcase student contributions, including bibliographies and annotations of Web sites. The project is an organic endeavor, with the Web site's organization open to periodic review and modification. Continuous discussions and mutual criticisms have marked the progress of the project. The authors see the success of this venture as a way to collaborate with more faculty, and increase the level of student participation on an ongoing basis.
\end{abstract}


Collaboration has always been an integral part of academic librarianship. In the words of Betsy Wilson, president of the Association of College and Resarch Libraries (ACRL), librarians "are the original collaborators in higher education. We come from a culture of cooperation, a culture that values the 'circle of gifts.'" (Wilson, 2000). This article discusses the efforts of two liaison librarians at William Russell Pullen Library, Georgia State University, to build a long-term, sustainable partnership among teaching faculty, graduate students, and librarians in the development and maintenance of a Web-based research guide for world history[1].

\section{Collaborative models}

To collaborate is to work jointly with others, especially in an intellectual endeavor. Following this definition, the most pervasive models of collaboration in librarianship are the reference interview and bibliographic instruction. These traditional activities are usually ignored in the literature on collaboration, perhaps because, being so pervasive, they do not stand out as particularly noteworthy. But as Betsy Wilson reminds us, working together is at the core of librarianship.

During the course of both the reference interview and bibliographic instruction, the librarian forges short-term relationships with faculty members and students that are focused on the satisfaction of immediate research/teaching needs. Following this model of collaboration, the librarian's role can be viewed as that of the more passive partner, reacting to the patron's expressed needs. Recent library literature reveals a more dynamic model of collaboration. Academic librarians are actively initiating partnerships with faculty and students. Much of the literature focuses on innovations in bibliographic instruction within the traditional classroom structure (Raspa and Ward, 2000).

Despite this new dynamism, however, the primary objective of librarian-faculty-student cooperation remains the accomplishment of a short-term goal in response to an immediate research/teaching request. The librarian's contribution is bibliographic expertise, providing instruction about how to locate and retrieve relevant materials. Thus the librarian is seen as an expert who is able to "find what the patron is looking for." This model of librarianship is based on Dr Samuel Johnson's distinction between types of knowledge: "Knowledge is of two kinds. We know a subject ourselves, or we know where we can find information upon it" (Cohen, 1995). This is the traditional distinction between teaching faculty, those who "know a subject," and librarians, those who view themselves as "keepers of the books" (Cook, 2000).

Several recent trends have helped to make possible more innovative approaches to collaboration (Farber, 1999). Among the most important are the rapid pace of technological change, especially the Internet, a focus on information literacy, and the growing popularity of the liaison model of librarianship. The Internet makes possible the documentation of a sustainable collaborative relationship between the library and the rest of the academic community. Information literacy stresses the importance of understanding the structure and "life-cycle" of information and the evaluation of information resources, in addition to facility with searching techniques. The liaison model centers on building closer ties between librarians with subject knowledge and teaching faculty and students, in the implementation of collection development, bibliographic instruction, and individualized reference 
consultation. All of these developments are helping to bridge the gap in Dr Johnson's knowledge division by marrying "knowledge of a subject" or subject expertise, with traditional librarianship, that of "knowing how to find information upon it."

\section{A useful model}

The World History Subject Guide project, developed by the library at Georgia State University (GSU), combines many of these dynamic elements. The project centers on the innovative use of technology, takes advantage of the liaison librarian structure, and involves faculty members and students in the creation of intellectual content. Its most distinctive feature lies in its futurity; that is, it is a work in progress, deriving its success from the continuing participation of librarians, faculty members, and students. It is an example of Raspa's and Ward's model of a fully collaborative enterprise, "a more pervasive, long-term relationship in which participants recognize common goals and objectives, share more tasks, and participate in extensive planning and implementation" (Raspa and Ward, 2000).

\section{Environment}

GSU is a state supported urban research institution in downtown Atlanta. Enrollment for fall semester 1999 was 23,492 students, 16,309 undergraduate and 7,101 graduate students (Georgia State University, 2000). The History Department at GSU offers bachelors, masters and PhD degrees, and at the start of fall semester 2000 was comprised of 25 full-time faculty members. The department is growing and anticipates adding two additional full time faculty per academic year for the next two years.

Pullen Library serves the GSU community with holdings of approximately 1.3 million volumes. As a federal depository, it houses approximately 851,587 government documents. A total of 5,296 serial titles were received in 1999. The Special Collections department in Pullen Library contains the university archives as well as the Georgia Women's Collections, Southern Labor Archives (the largest accumulation of labor records in the Southeast), and the Popular Music collection (including the papers of Johnny Mercer). As a member of the University System of Georgia, GSU students, faculty and staff have access to GALILEO; a Web interface to over 100 databases indexing thousands of periodicals and scholarly journals. Over 2,000 journal titles are provided in full text. In addition to GALILEO, Pullen Library subscribes to electronic journals in various disciplines and over 100 specialized research databases[2].

Prior to 1998, four bibliographers, each responsible for a broad subject area (humanities, social sciences, business, and education), carried out all collection development activities. Their duties focused on selection of materials, collection maintenance (weeding, replacements, gifts), collection assessment specialized consultations and some subject-specific bibliographic instruction. They had no reference responsibilities.

In the fall of 1998, Pullen Library reorganized the structure of the existing Reference and Collection Development units by implementing the liaison model. Several factors led to this change, foremost being the desire of the new library director to move to this model. Other factors included an expanding university curriculum and research base, the explosion of electronic information resources, and the need to better integrate library services into the activities of the university. In addition, the university 
and its governing body, the Board of Regents, strongly encouraged (and continues to encourage) campus-wide partnerships not only between faculty members of different colleges, but also between teaching faculty and academic support service faculty (librarians and counselors). In fact, it was the Regents' desire for collaboration between the College of Education and the College of Arts and Sciences that led to the creation of the faculty member's position in the Department of History.

The liaison librarian model that is now in place consists of 18 librarians, each responsible for collection development activities for specific departments. When the model is fully implemented, each librarian will be responsible for no more than two departments. Liaison librarians have extensive subject knowledge and, in many cases, a second master's degree in their assigned subject areas. In addition to collection development, liaison librarians are responsible for general reference desk hours (unless their primary appointment is in technical services), customized bibliographic instruction classes, and specialized research assistance. As the Pullen Library Strategic Plan states:

Liaisons will partner with the faculty, academic departments and interdisciplinary programs and students ... to be even more responsive and comprehensive in the delivery of information services to our academic community (William Russell Pullen Library, 2000).

\section{Genesis of the Web project}

The idea of creating a Web site for world history occurred to one of the authors while auditing a graduate history seminar, "Issues and Interpretations in World History," in Fall 1998. This was a new course, taught by a young faculty member who had been recently hired to develop this relatively new field in history. The seminar is currently mandatory for all history PhD students, and consistently attracts a large number of history MA candidates, as well as students from departments other than history. Large numbers of students in the College of Education who are pursuing a master's degree in education are also among those who take this course.

What attracted the co-author to the course was its interdisciplinary framework. As the liaison for philosophy and religious studies, she saw the need to develop subject expertise in related areas, history in particular, in order to serve her department more effectively. She was also, personally, interested in pursuing a doctorate, and history seemed a likely field since the Philosophy Department did not offer a degree beyond the masters level. The interdisciplinary nature of world history was strongly emphasized by the professor. He stressed that this emerging field in history included the scholarship of experts in a number of disciplines outside history: sociology, human and physical geography, economic history, religious studies, political science, and other fields. This collaborative aspect was also evident from the class syllabus in which 64 assigned/recommended texts represented 13 different subject areas ranging from art to technology. These areas were classed in 29 different call numbers, with subject headings from anthropology to technology transfer.

Given such a broad range of resources, the graduate students faced a stiff challenge in navigating the research process. The librarian auditing the course became the de facto class librarian, providing research help to fellow students. The idea of a Web site that would consolidate and centralize these research "tips" arose naturally from this experience. The faculty member was immediately enthusiastic - 
an important key to the eventual success of this project. When a new history liaison joined Pullen Library in the fall of 1998, she readily agreed to participate in the Web project. Both librarians saw the project as an opportunity to put into practice the philosophy of the liaison model.

\section{The project: process and design}

As we began to discuss our ideas about the Web site, it became clear that each of us brought unique talents and differing perspectives to the project. Rather than creating a Web pathfinder for the graduate seminar, a more interactive model was developed. The History Department liaison librarian was particularly interested in having students annotate Web links as they searched for, and evaluated, Internet resources. This model was embraced by the planning group as an innovative way of reinforcing students' critical thinking skills beyond the duration of the seminar. The faculty member offered the services of his graduate assistant, and also suggested that other history faculty members might be brought into the project by contributing Web site suggestions and specialized bibliographies.

Through a series of meetings, the main objectives of the project were discussed and agreed upon. As we state on our home page, these goals include:

* to provide access to the resources available at the Pullen Library;

* to serve as a gateway to resources available on the Internet; and

* to showcase student contributions, including bibliographies and annotations of Web sites.

\section{Site design}

Using the template we had developed for previous Web sites, we decided to organize the site according to format: general reference resources, databases, and Internet resources. Because the focus was to be on Internet resources, this category was broken down further into the following subcategories: general Web sites; list servs and directories; e-journals; maps; bibliographies; and world history syllabi. We envisioned additional topical subdivisions according to themes covered in the seminar and listed on many of the syllabi we had retrieved from the Internet. We used as the model for these topical subdivisions the bibliography developed by one of the pioneers of the study of world history, Jerry Bentley. This bibliography had been circulating "underground" among world historians and had been used by the faculty member as the basis for his own course syllabus. The faculty member and his research assistant developed the final list of categories. Among the topics included are: historiography; cross-cultural encounters; migrations and diasporas; religious conversion; economics and trade; and nomads.

The Web design was adapted from a template used by the history liaison for class guides. It had already been used by the co-authors for a previous collaborative project, a Web site done in conjunction with a joint bibliographic instruction class for Roman history. Because we wanted the focus to be on the content, we settled on a simple design: a table of contents main page, with links to the following modules: searching the online catalog; general reference resources; databases; Internet resources. Given our differing expertise and professional experience, there was a natural division of labor. 
Searching the catalog and general reference resources fell to the liaison with cataloging expertise; databases, to the liaison with reference experience; Internet resources, to both liaisons and the faculty member and his assistant. We agreed that the Web site would be organic, with its organization open to periodic review and modification. In fact, it was the flexible nature of the Web that attracted us to using this medium for our research guide. Continuous discussions and mutual criticisms marked the progress of our project.

Other steps in the development of the project included the creation of guidelines for selecting and annotating sites to be linked on the guide and a form for students to complete in order to submit the sites for consideration. After looking at other academic library and librarian Web sites, the LOEX Clearinghouse for Library Instruction[3], and the ALA Library Instruction Roundtable Website Evaluation Criteria[4], we devised a list of factors to consider when selecting a Web site for inclusion on the guide. These included the standard criteria such as authority, reliability, currency, etc. As the Web guide evolves, we plan to add more detailed criteria for selecting Web sites specifically relevant to the subject of the guide - world history. To date, graduate students have chosen to annotate sites already selected by the two librarians, so this issue has not been a priority yet.

Along with developing the criteria, the librarians devised a form to be completed by anyone suggesting a Web site for inclusion on the guide. Again, informal face-to-face meetings among the librarians, faculty member and graduate assistant took place. The graduate assistant used the first draft of the form to annotate several sites, and then we all met again to discuss revisions to the form. After the fields to be included on the form were finalized, the form was mounted on the library Web site using the software program, FrontPage. The basic format was adopted from the Internet public library's Web site[5].

\section{Status of the project}

The Web site was posted in January 2000 and remains a work in progress. It was included in a proposal to the History Department to develop a world history program at the bachelor's and master's degree levels, along with plans to subsequently establish a World History Center at the university. It is also part of the syllabus for the World History seminar.

The co-authors conducted an extensive bibliographic instruction session demonstrating the site to the seminar class, and the history liaison has been promoting the site during bibliographic instruction sessions for the "Introduction to Historical Studies" and "Introduction to Historical Research" classes. These courses, required of both undergraduate majors and graduate students in history, are taught by faculty every semester on a rotating basis. During Spring Semester 2000, students in the World History seminar were given the option of submitting three annotations of Web sites to be included on the guide in lieu of the course requirement of a posting on the H-Net Listserv[6]. One student took this option, and submitted three annotations. During Fall Semester 2000, two undergraduate honors students worked on projects that will contribute to the site, including annotated bibliographies and short essays on topics they have chosen in consultation with the world history professor. In addition, a graduate assistant in the History Department is annotating the existing links on the guide and submitting those throughout the semester. 


\section{Project outgrowth}

Other history faculty have expressed interest in having similar Web guides for their subject areas. For example, the history liaison is currently collaborating with a faculty member in the History Department and the head of Special Collections and Archives to initiate a Web-based project on Southern immigration history. The philosophy and religious studies liaison has used the site to generate interest for bibliographic instruction in her department, which has been notorious for its indifference to bibliographic instruction. The result was the first bibliographic instruction class ever taught in philosophy as well as numerous requests for Web research guides in various aspects of this discipline. She is currently working with a philosophy graduate research assistant to select Web sites for seminars on Nietzsche and Phenomenology. She is also collaborating with the political science liaison on a Web resource guide for a Spring 2001 seminar on the history of political philosophy. The seminar is crosslisted for political science and philosophy majors and graduate students. Cross-listed courses are becoming increasingly popular at GSU, a development that should afford increasing collaborative opportunities for Pullen Library liaisons.

The co-authors are planning further collaborative projects including a Web research guide on the Holocaust, and one focusing on ancient history. Our faculty collaborator will be teaching an upper-level undergraduate course, "Cross-Cultural Encounters," in Spring 2001 and we intend to expand the current section of the guide on this topic to include student bibliographies and annotations of pertinent Web sites. This course will most likely become a regular offering and be taught by various history faculty members. We see this as a promising way to collaborate with more faculty in the department, and increase the level of student participation in the guide.

\section{Future of project}

Although we cannot predetermine the direction of the project - this is part of its dynamic nature - we foresee a number of enhancements. We hope to involve more undergraduate honors students from various history courses in the annotation of Web sites. We see the need to tailor the Web selection criteria more closely to the specific topical categories and ensure that the students are meeting the learning outcomes that we intend. We also expect to devise a plan to recruit other history faculty to participate in the project. To date, we have promoted the site to a limited number of people in the GSU

community, having agreed to hold back on advertising the site until it is more fully developed. However, we have brainstormed ways that we could promote the guide to a wider audience. These include a presentation of the site and discussion of the collaborative nature of the project at a history or other departmental "brown bag" or lecture series; an article in the bi-monthly Pullen Library Newsletter, and articles in other humanities departmental newsletters. Because we all believe that the collaboration on this project was a success, and want to encourage other academic librarians and teaching faculty to embark on a similar collaborative project, we plan to submit a proposal to discuss the project at a nationwide conference, for example, the annual World History Association meeting. Developing and presenting a paper or workshop at this conference would be yet another cooperative effort on the part of the project's creators. To promote the site on a broad scale, we plan to post a message on H-WORLD, a "discussion list [that] serves as a network of communication among practitioners of world history [and] 
gives emphasis to research, to teaching, and to the connections between research and teaching" [7]. We feel this would be an appropriate venue for this kind of information, because the discussion list highlights links between doing research and teaching world history.

As the guide grows in complexity and is promoted on a wider scale, we know it is imperative to investigate creative ways of adding new material, maintaining the site, and providing easy access to its contents. The recent addition of a Web librarian to the Pullen faculty should prove helpful with these issues. An exciting new opportunity for enhancing our Web project is Pullen Library's recent decision to participate in CORC (Cooperative Online Resource Catalog), OCLC's collaborative project to catalog Internet resources. The catalog liaison co-author is currently the library professional responsible for reviewing and cataloging harvested Web sites. We plan to catalog the links on our Web guide within the next few months, and to set up a regular schedule for harvesting and cataloging additional links as these are forwarded to us by students and faculty. Having full catalog records of our Web links in our OPAC, with call numbers and subject headings, will facilitate greater patron access to our site. We also intend to add Library of Congress subject headings to the listings within the various categories, e.g. sources listed under historiography, religious conversion, etc.

In addition to enhancing access to resource materials on the Internet, another important goal of our project is to focus attention on Pullen Library resources. Towards this end, we will be adding an additional feature to the site, highlighting recent additions of monographs, media materials, and locally accessible electronic databases. As liaisons, we see all new materials as they arrive in the library, so it should be fairly easy to tag items appropriate for inclusion in this "What's new?" category. This list could be disseminated to interested faculty and graduate departments via e-mail.

We believe that this project has enhanced the visibility of librarians among teaching faculty and students, resulting in better understanding of the importance of the library professional to the educational process. The project has built bridges within the library and between the library and the rest of the GSU community. As we continue to develop and enhance our Web guide, we hope to establish connections with the wider intellectual community by providing a centralized resource for the study and teaching of world history.

An important practical consideration for us is time management. The key idea behind the liaison model is closer collaboration between librarians and teaching faculty. As we have discovered, such collaboration requires a substantial investment of time and energy. Throughout the project, we have met ad hoc and used e-mail to maintain the collaborative relationship. The history faculty member has suggested that a regular meeting time, perhaps a monthly or bimonthly coffee break, would be very advantageous to him for keeping the project on track. The more successful a project becomes, the more time it seems to require. As we have already experienced, other faculty are interested in working with us on similar projects. Balancing our other professional responsibilities with the maintenance and oversight of one, let alone multiple, on-going collaborative projects will be a major challenge. 


\section{Conclusion}

Working on this project has been a rewarding personal and professional experience. We have come to have a deep appreciation of each other's expertise and dedication to librarianship. Through our extensive discussions and planning sessions, we have become more open to experimentation, and less welded to preconceived notions about what can and cannot be done. We are now more flexible in dealing with the invisible glitches and setbacks. In addition, we have come to fully appreciate the value of criticism and the intellectual give-and-take that is a large part of any successful collaboration. Working with teaching faculty and students has given us a renewed stake in the education mission of the GSU community.

Our experience attests to the truth of Raspa's and Ward's observation that collaboration requires a "significant effort, lots of time, and a desire to make things happen" (Raspa and Ward, 2000). We point to desire as the key to success. Without a true passion for creating a link between librarianship and the discipline of world history it would have been difficult, if not impossible, to find the time or sustain the effort required to make the project a success. Working on this project has been, in the best sense, an educational process for us. In attempting to educate our students, we are educating ourselves. And this may be the greatest benefit of this collaboration.

\section{Notes}

1 University System of Georgia (2000), "Galileo Home Page", available at http://www.galileo.peach net.edu

2 William Russell Pullen Library (2000), "William Russell Pullen Library, Georgia State University", available at http://www.library.gsu.edu

3 LOEX Clearinghouse for Library Instruction (2000), "Instruction links: evaluating Web resources", available at http://www.emich.edu/public/loex/ ISLINKS/EWELINKS.HTM

4 Library Instruction Roundtable Research Committee (2000), "Website evaluation criteria", available at http://diogenes.baylor.edu/Library/LIRT/lirtcrit.html

5 The Internet Public Library (2000), "The Internet public library lobby", available at http://www.ipl.org 6 H-Net (2000), "H-World", available at http://www2. h-net.msu.edu/-world/

7 See Sugarman, T., Demetracopoulos, C. and Rapp, S. (2000), "World History Subject Guide", available at: http://www.library.gsu.edu/worldhistory/home.htm 


\section{References}

Cohen, C. (1995), "Faculty liaison: a cooperative venture in bibliographic instruction", The Reference Librarian, No. 51-52, pp. 161-9.

Cook, D. (2000), "Creating connections: a review of the literature", in Raspa, D. and Ward, D. (Eds), The Collaborative Imperative: Librarians and Faculty Working Together in the Information Universe, Association of College and Research Libraries, Chicago, IL, pp. 19-38.

Farber, E. (1999), "Faculty-librarian cooperation: a personal retrospective", Reference Services Review, Vol. 27 No. 3, pp. 229-34.

Georgia State University Office of Institutional Research (2000), "Common Data Set B: Enrollment and Persistence", Georgia State University, Atlanta, GA, http://www.gsu.edu/-wwwire/datasetB.html

Raspa, D. and Ward, D. (2000), "Listening for collaboration: faculty and librarians working together", in Raspa, D. and Ward, D. (Eds), The Collaborative Imperative: Librarians and Faculty Working Together in the Information Universe, Association of College and Research Libraries, Chicago, IL, pp. 1-18.

William Russell Pullen Library (2000), "Strategic plan", Georgia State University, Atlanta, GA, http:II www.library.gsu.edu/About/admin/strategicplan.htm

Wilson, B. (2000), "The Lone Ranger is dead", College and Research Libraries News, Vol. 61 No. 8, September, pp. 698-701.

\section{Author Note:}

The authors would like to thank Dr Stephen Rapp for his interest and participation in this project. 